\title{
Validation of the Chinese Version of the Epistemic Beliefs Inventory Using Confirmatory Factor Analysis
}

\author{
Xihui Wang ${ }^{1}$, Zhidong Zhang ${ }^{2}$, Xiuying Zhang ${ }^{3} \&$ Dadong $\mathrm{Hou}^{4}$ \\ ${ }^{1}$ Faculty of Education, McGill University, Quebec, Canada \\ ${ }^{2}$ College of Education, The University of Texas at Brownsville, USA \\ ${ }^{3}$ College of Humanities and Law, North China University of Technology, Beijing, China \\ ${ }^{4}$ Faculty of Education, McGill University, Quebec, Canada \\ Correspondence: Xihui Wang, Faculty of Education, McGill University, QC., H9W 2B2, Canada. Tel: \\ 1-514-679-0068. E-mail: xihui.wang@mail.mcgill.ca
}

Received: June 26, 2013 Accepted: July 22, $2013 \quad$ Online Published: July 29, 2013

doi:10.5539/ies.v6n8p98 URL: http://dx.doi.org/10.5539/ies.v6n8p98

\begin{abstract}
The Epistemic Beliefs Inventory (EBI), as a theory-based and empirically validated instrument, was originally developed and widely used in the North American context. Through a strict translation procedure the authors translated the EBI into Chinese, and then administered it to 451 students in 7 universities in mainland China. The construct validity of scores on the Chinese version of the EBI (EBI-C) was examined with confirmatory factor analysis (CFA). The results confirmed the original 5 factors: Simple Knowledge (SK), Certain Knowledge (CK), Innate Ability (IA), Omniscient Authority (OA), and Quick Learning (QL). Yet the overall model fit was unsatisfactory, $\chi^{2}(449)=1167.32, \mathrm{GFI}=.85$, and RMSEA $=.06$. After two model respecifications with interpretable solutions, the overall model fit was substantially improved with $\chi^{2}(265)=510.81, \mathrm{GFI}=.92$, RMSEA $=.04$. The EBI-C can be used in China and other Chinese-speaking regions and communities. Cross-cultural research in the area of epistemic beliefs becomes more feasible because of the presence of the parallel instrument.
\end{abstract}

Keywords: epistemic beliefs; confirmatory factor analysis, Chinese context

\section{Introduction}

\subsection{Epistemic Beliefs and Cross-Cultural Studies}

Epistemic beliefs refer to individuals' beliefs about the nature of knowledge and knowing (Hofer \& Pintrich, 1997). Research studies present that epistemic beliefs have direct and indirect effects on students' learning such as the types of learning strategies that students use (Muis \& Franco, 2009; Schommer, Crouse, \& Rhodes, 1992), their self-regulated learning (Muis, 2008), their use of metacognitive strategies (Muis \& Franco, 2010), their readiness for conceptual change (Franco et al., 2012), and more generally their cognitive processing (Kardash \& Howell, 2000).

Researchers in this field have been trying to conceptualize and theorize this construct using different theoretical frameworks, among which multidimensionality of epistemic beliefs is one of the most widely accepted (Hofer \& Pintrich, 1997; Kuhn, Weinstock, \& Flaton, 1994; Perry, 1970; Schommer, 1990;). In this framework personal epistemology was conceptualized either as having a finite number of dimensions or as having an infinite number of resources (Hofer \& Pintrich, 1997; Schommer, 1990). Models in this framework provide a valuable tool for apprehending the nature of epistemic beliefs, and for further exploring the relations between epistemic beliefs and other learning constructs.

Over the last decade, cross-cultural differences in epistemic beliefs have been increasingly studied and recognized. Some studies have examined a single cultural context to replicate or validate western-based findings (Brownlee, Walker, Lennox, Exley, \& Pearce, 2009; Cano, 2005; Chan \& Elliott, 2002; So, Lee, Roh, \& Lee, 2010), others have compared the differences between contrasting cultures such as individualism versus collectivism (Hofer, 2001, 2007, Karabenick \& Moosa, 2005; Qian \& Pan, 2002; Schreiber \& Al-Ghalib, 2007; Zhu, Valcke, \& Schellens, 2008), and still some others have compared epistemic beliefs between similar cultures 
(Estes, Chandler, Horvath, \& Backus, 2003; Haerle \& Bendixen, 2008; Muis \& Sinatra, 2008; Sulimma, 2009). Evidence has been mounting to support that cultural differences exist in both epistemic structure (Qian \& Pan, 2002; Youn, 2000), and epistemic belief development (Gottlieb \& Institute, 2007; Zhang \& Watkins, 2001), especially between contrasting cultures like those of North America and East Asia.

\subsection{Epistemic Beliefs Inventory (EBI)}

Schraw and his colleagues (Schraw, Bendixen, \& Dunkle, 2002) developed the Epistemic Belief Inventory (EBI) to investigate the dimensions of epistemic beliefs. The EBI is modeled on Schommer's (1990) four-factor instrument, Epistemological Questionnaire (EQ). The EBI started as a 32-item instrument (Bendixen, Schraw, \& Dunkle, 1998), a revision of which subsequently resulted in a 28 -item version. The current version of the EBI, which has been validated in the western cultural context, comprises five factors. Each factor represents one facet of epistemic beliefs: Simple Knowledge (SK), Certain Knowledge (CK), Innate Ability (IA), Omniscient Authority (OA), and Quick Learning (QL), structured on a five-point Likert scale that ranges from 1 to 5 corresponding to strongly disagree to strongly agree.

The EBI has been extensively used to examine epistemic beliefs in relation to other educational constructs, including cognitive engagement (Ravindran, Greene, \& Debacer, 2005), critical thinking (Chan, Ho, \& Ku, 2011), self-efficacy (Nietfeld \& Enders, 2003), self-regulated learning strategies (Ayatollahi, Rasekh, \& Tavakoli, 2012), and students' dispositions to engage in argument (Nussbaum \& Bendixen, 2003). Moreover, there has been a growing body of research on epistemic beliefs using the EBI in other cultural contexts. For example, the EBI has been translated and adapted for the use in Korea (Jeong, 2003), China (Chan et al., 2011), Germany (Paechter et al., 2013), and Turkey (Cam, Topcu, Sulun, Guven, \& Arabacioglu, 2012).

There have been also growing interest in examining the factor structure of the EBI (Teo \& Chai, 2011), in comparing and combining the EBI with other epistemic beliefs instruments (Duell \& Schommer-Aikins, 2001; DeBacker, Crowson, Beesley, Thoma, \& Hestevold, 2008; Ordoñez, Ponsoda, Abad, \& Romero, 2009; Laster, 2010), and in studying its psychometric properties (Teo, 2013; Welch \& Ray, 2012). For a comprehensive comparison of previous psychometric analyses of the EBI, please refer to Welch and Ray (2012).

A comparison of the EBI and the EQ (Schraw, Bendixen, \& Dunkle, 2002), based on the exploratory factor analyses of the data from the same sample, showed that the EBI yielded the five hypothesized factors described above while the EQ generated four. In addition, the EBI explained substantially more sample variation than the EQ. A comparison of Cronbach's $\alpha$ indicated that the two instruments were quite similar on the internal reliability. However, the EBI had considerably better test-retest reliability than the EQ. Furthermore, the EBI demonstrated better predictive validity than the EQ when correlated with student achievement in reading comprehension. Overall, the five factors identified by the EBI provided a close fit with the five epistemic dimensions hypothesized by Schommer (1990) and resulted in a much more parsimonious model.

\subsection{EBI-Chinese Version}

It is highly desirable that a theory-based and empirically validated instrument like the EBI be adapted for use in China as well as other Chinese-speaking regions and communities. Accordingly, the 32 -item version of the EBI was chosen for the translation and validation purpose. By doing this our ultimate goal was to develop an instrument that is suitable to measure epistemic beliefs of Chinese samples.

\subsection{Validation of the EBI Chinese Version}

Ideally a translated test should possess a quality that demonstrates linguistic and construct equivalence to the original instruments (Brislin, Lonner, \& Thorndike, 1973; Lonner, 1985, 1990). Such a quality ensures that items on the two versions of the instrument have the same meaning and measure the same underlying construct of interest. The translation process in the present study followed a three-step procedure described by Hansen (1987) for establishing linguistic and inferential equivalence. The English version of the EBI was first translated into Chinese by a Chinese-speaking researcher, proficient English in the area of epistemic beliefs research. The Chinese version was then back-translated into English by a second bilingual translator who is very experienced in Chinese/English translation but has no content knowledge about epistemic beliefs. The back-translated version was then compared with the original EBI by another bilingual speaker proficient in both English and Chinese who has done research studies in the area of epistemic beliefs. Based on the comparison he then came up with a new Chinese version. The three translators then had a discussion on the two versions and reached a final agreement. Overall, most items did not have major differences in meaning, and only a few items were modified either to improve the semantic meaning or to maintain conceptual meaning. 


\subsection{Statement of the Problem}

One plaguing measurement issue for most cross-cultural studies of epistemic beliefs is the lack of the instruments that allow for parallel studies and cross-cultural comparison (Cole \& Bruner, 1971; Hofer, 2008; Palmer \& Marra, 2008). To solve this problem, existing instruments need to be adapted for wider audiences and contexts, and new instruments that are less culturally biased need to be developed (Buehl, 2008). To this end, the current study was undertaken to adapt the Epistemic Beliefs Inventory (EBI) for use in the Chinese context.

\subsection{Research questions}

The following three research questions were asked to properly focus the study on the validation of the Chinese version of the epistemic belief inventory.

1) Is there any difference between the Epistemic Belief Inventory and the Chinese version of the EBI in measuring epistemic belief construct?

2) How can we examine the components of the epistemic belief construct in a Chinese cultural context using a factor analysis procedure?

3) How can the final EBI model be used effectively to describe the different dimensions of epistemic belief knowledge and cognitive engagement?

\section{Method}

\subsection{Sample}

The sample consists of 287 female and 164 male undergraduates, from 7 universities - two in South China, two in Central China, and three in North China. Participants ranged in age from 17 to 32 years $(M=19.35, S D=$ 1.33). Approximately $98.7 \%$ of participants were under 22 , and among them $50.6 \%$ were freshmen, $37.5 \%$ sophomores, $5.5 \%$ juniors, and $2.2 \%$ seniors. This sample contains more freshmen but fewer juniors as compared to Schraw, Bendixen and Dunkle's (2002) sample.

\subsection{Instrument and Procedure}

The Chinese version of the EBI (see Appendix B) which uses a 5-point Likert scale item response format, with 1 as "strongly disagree" and 5 as "strongly agree", parallels the original 32-item EBI (see Appendix A). Appendix A shows how the 32 items as measured variables are grouped under five factors: (a) Simple Knowledge ( 8 items) ranges from knowledge as compartmentalized as isolated bits to knowledge as highly integrated and interwoven; (b) Certain Knowledge (7 items) measures knowledge as absolute to knowledge as constantly evolving; (c) Innate Ability ( 7 items) ranges from ability to learn as genetically predetermined to ability to learn as acquired through experience; (d) Omniscient Authority (5 items) measures from knowledge as handed down by omniscient authority to knowledge as reasoned out through objective and subjective means; and (e) Quick Learning (5 items) measures from learning as quick or not-at-all to learning as a gradual process (Schraw, Bendixen, \& Dunkle, 2002). The questionnaire was distributed to the participants through a web-based survey service-Surveygizmo (Surveygizmo, 2013).

\section{Data Analysis}

A confirmatory factor analysis (CFA) was conducted using the EQS program (Bentler \& Wu, 2013). Referring to the original EBI model, the CFA analysis of the data collected via EBI-C validates each item and theoretical construct of the EBI-C.

Altogether 515 students took part in the study, and 491 completed the questionnaire. Reverse coding is required for items 2, 6, 14, 20,30,31, and was thus applied. Based on the critical value of Mahalanobis Distance of 53.49 (at the level of .01), 40 cases were identified as multivariate outliers and were deleted. The sample for EQS analysis was 451 . Skewness values for all items were considered satisfactory.

\section{Results}

Confirmatory factor analysis was used to test the five-factor structure of the EBI-C. The initial model showed unsatisfactory fit; the post-hoc analyses were more exploratory in nature, in which two respecifications were incorporated to adjust the model fit. The second adjusted model turned out good model fit. Table 1 presents fit statistics for the three models. 
Table 1. Fit indices for the confirmatory factor analysis models

\begin{tabular}{llllll}
\hline Model & $d f$ & RMR & GFI & RMSEA & AGFI \\
\hline Initial Model & 449 & .05 & .85 & .06 & .82 \\
Adjusted Model 1 & 289 & .04 & .90 & .05 & .88 \\
Adjusted Model 2 & 265 & .03 & .92 & .05 & .90 \\
\hline
\end{tabular}

Different model specifications resulted in different number of items in each subscale. But overall its scores have been shown to have adequate reliability (see Table 2).

\subsection{The Initial Model}

With the CFA model of the EBI-C it was hypothesized that (a) responses to the EBI-C can be explained by five factors: SK (with item 1, 10, 11, 13, 18, 22, 24, 30), CK (with items 2, 6, 14, 19, 23, 25, 31), IA (with items 5, 8, $12,15,17,26,32$ ), OA (with items 4, 7, 20, 27, 28) and QL (with items 3, 9, 16, 21, and 29); (b) each item has a nonzero loading on the factor that it is meant to measure, and has zero loadings on all other factors; (c) the five factors are correlated; and (d) the error terms associated with each item are uncorrelated. The model was run with all the parameters to be freely estimated.

Results showed that data are non-normally distributed, with the Mardia's normalized estimate as $16.38(>5.00)$. Yet since the estimates of the five cases pointed by the program are not distinctively different and fell approximately within the same range of values, none of the cases was taken out. ML robust should be run in the post-hoc analyses.

The average off-diagonal absolute standardized residual was $.06(<2.58)$, and residual distribution was centered around zero and symmetric. The overall model fit showed $\chi^{2}(449)=1167.32, \mathrm{GFI}=.85$, and RMSEA $=.06$, within the $90 \%$ confidence interval between .055 and .064 . Cronbach's alpha $=.72$. And altogether 8 iterations were run to reach the convergence.

Parameter estimates showed that the estimates for SK, item 4, item 22, item 24 and item 30 were not statistically significant, and that the covariance between SK and OA, between SK and QL, and between CK and IA were not significant (.07, .12 and .02 respectively). For the post-hoc analyses decisions were made to (a) keep SK as a factor; (b) drop items 4, 22, 24 and 30, since the latter three being not significant could have caused SK to be an insignificant factor; (c) drop the covariance parameter estimates of SK/OA, due to the above-mentioned problem that SK had; (d) drop the covariance parameter estimates of SK/QL and CK/IA, in response to Hofer and Pintrich's (1997) argument that QL and IA as beliefs about learning should be distinguished from core dimensions of epistemic beliefs like SK and CK.

Conformed with the findings in the above paragraph, the Wald Test showed that the paths of (a) SK/OA, (b) SK/QL, and (c) CK/IA, should be dropped, that (d) SK should be dropped as a factor and that (e) item 4 should be dropped from OA. Decisions and justifications regarding the first four have already been made. For item 4, the actual statement "People should always obey the law", was found to relate "authority" to a very general sense of "power", rather than as defined (measuring from knowledge as handed down by omniscient authority to knowledge as reasoned out through objective and subjective means). Statements regarding the authority of experts, professors, textbooks, or media would be more suitable for tapping into individuals' epistemic beliefs. Therefore, item 4 was taken out in the post-hoc analysis.

From the ML test results, cross-loadings were found between the following pairs of variables: item 24 and CK, item 9 and SK, item 32 and CK, item 20 and CK. There was an error covariance between items 32 and 17. Item 24 was not a significant variable and would be excluded from the nest new model. Item 9 was considered to measure people's understanding of the simplicity of knowledge, thus a path between item 9 and SK was to be added. Evidently, item 32 relates directly to IA rather than CK, thus the path would remain the same for the post-hoc analysis. Item 20 , although mostly about "authority", had a same problem as item 4 , in failing to capture the meaning that the item was intended to measure. Therefore, a path between item 20 and CK would be added to compare the loadings. Items 32 and 17 were considered to have the same intended meaning, thus a path between them was added.

Based on the loadings of each variable, item 1(.14), 3(.13), 4(-.07), 22 (.11), 24(-.16), and 30(-.20) were deleted, while item $13(.54), 31(.54), 5(.68), 28(.74)$, and 16(.64) were designated as marker variables. The item-factor coefficients and inter-factor correlations for this model are presented in Table 3 and 4. 
Table 2. Reliabilities, $90 \%$ confidence interval of RMSEA and number of items in the scales

\begin{tabular}{|c|c|c|c|c|c|c|}
\hline & $\begin{array}{l}\text { No. of Items } \\
\text { in the Model }\end{array}$ & $\begin{array}{l}\text { Cronbach's } \\
\text { alpha }\end{array}$ & CI & & $\begin{array}{l}\text { No. of } \\
\text { Items }\end{array}$ & Items in the Scales \\
\hline \multirow[t]{5}{*}{$\begin{array}{l}\text { Initial } \\
\text { Model }\end{array}$} & 32 & .72 & $\begin{array}{l}0.055, \\
0.064\end{array}$ & SK & 8 & $1,10,11,13,18,22,24,30$ \\
\hline & & & & CK & 7 & $2,6,14,19,23,25,31$ \\
\hline & & & & IA & 7 & $5,8,12,15,17,26,32$ \\
\hline & & & & OA & 5 & $4,7,20,27,28$ \\
\hline & & & & QL & 5 & $3,9,16,21,29$ \\
\hline \multirow[t]{5}{*}{$\begin{array}{l}\text { Adjusted } \\
\text { Model } 1\end{array}$} & 26 & .74 & $\begin{array}{l}0.05 \\
0.06\end{array}$ & SK & 4 & $10,11,13,18$ \\
\hline & & & & $\mathrm{CK}$ & 7 & $2,6,14,19,23,25,31$ \\
\hline & & & & IA & 7 & $5,8,12,15,17,26,32$ \\
\hline & & & & OA & 4 & $7,20,27,28$ \\
\hline & & & & QL & 4 & $9,16,21,29$ \\
\hline \multirow[t]{5}{*}{$\begin{array}{l}\text { Adjusted } \\
\text { Model } 2\end{array}$} & 25 & .74 & $\begin{array}{l}0.04, \\
0.05\end{array}$ & SK & 5 & $9,10,11,13,18$ \\
\hline & & & & CK & 8 & $2,6,14,19,20,23,25,31$ \\
\hline & & & & IA & 6 & $5,8,12,15,17,26$ \\
\hline & & & & OA & 3 & $7,27,28$ \\
\hline & & & & QL & 3 & $6,21,29$ \\
\hline
\end{tabular}

Table 3. Maximum-likelihood coefficients for the EBI-C (initial model)

\begin{tabular}{|c|c|c|c|c|c|c|}
\hline Items & & SK & $\mathrm{CK}$ & IA & $\mathrm{OA}$ & QL \\
\hline 1 & $\begin{array}{l}\text { It bothers me when instructors don't tell students the } \\
\text { answers to complicated problems. }\end{array}$ & .14 & & & & \\
\hline 10 & Too many theories just complicate things. & .50 & & & & \\
\hline 11 & The best ideas are often the most simple. & .43 & & & & \\
\hline 13 & Instructors should focus on facts instead of theories. & .54 & & & & \\
\hline 18 & $\begin{array}{l}\text { Things are simpler than most professors would have you } \\
\text { believe. }\end{array}$ & .51 & & & & \\
\hline 22 & $\begin{array}{l}\text { Science is easy to understand because it contains so } \\
\text { many facts. }\end{array}$ & .11 & & & & \\
\hline 24 & $\begin{array}{l}\text { The more you know about a topic, the more there is to } \\
\text { know. }\end{array}$ & -.16 & & & & \\
\hline 30 & $\begin{array}{l}\text { You can study something for years and still not really } \\
\text { understand it. }\end{array}$ & -.20 & & & & \\
\hline 2 & Truth means different things to different people. & & .42 & & & \\
\hline 6 & Absolute moral truth does not exist. & & .38 & & & \\
\hline 14 & $\begin{array}{l}\text { I like teachers who present several competing theories } \\
\text { and let their students decide which is best. }\end{array}$ & & .35 & & & \\
\hline 19 & $\begin{array}{l}\text { If two people are arguing about something, at least one } \\
\text { of them must be wrong. }\end{array}$ & & 47 & & & \\
\hline 23 & The moral rules I live by apply to everyone. & & .41 & & & \\
\hline 25 & What is true today will be true tomorrow. & & 46 & & & \\
\hline 31 & $\begin{array}{l}\text { Sometimes there are no right answers to life's big } \\
\text { problems. }\end{array}$ & & .54 & & & \\
\hline 5 & $\begin{array}{l}\text { Some people will never be smart no matter how hard } \\
\text { they work. }\end{array}$ & & & .68 & & \\
\hline 8 & $\begin{array}{l}\text { Really smart students don't have to work as hard to do } \\
\text { well in school. }\end{array}$ & & & .66 & & \\
\hline 12 & People can't do too much about how smart they are. & & & .56 & & \\
\hline 15 & $\begin{array}{l}\text { How well you do in school depends on how smart you } \\
\text { are. }\end{array}$ & & & .55 & & \\
\hline 17 & Some people just have a knack for learning and others & & & .62 & & \\
\hline
\end{tabular}


don't.

26 Smart people are born that way. .59

32 Some people are born with special gifts and talents. .35

$4 \quad$ People should always obey the law.

7 Parents should teach their children all there is to know $-.07$ about life.

20 Children should be allowed to question their parents' authority.

27 When someone in authority tells me what to do, I usually do it.

28 People who question authority are trouble makers.

3 Students who learn things quickly are the most successful.

9 If a person tries too hard to understand a problem, they will most likely end up being confused.

16 If you don't learn something quickly, you won't ever learn it.

21 If you haven't understood a chapter the first time through, going back over it won't help.

29 Working on a problem with no quick solution is a waste of time.

Table 4. Inter-factor correlation matrix for the EBI-C (initial model)

\begin{tabular}{llllll}
\hline & SK & CK & IA & OA & QL \\
\hline SK & 1.00 & & & & \\
CK & -.38 & 1.00 & & & \\
IA & .36 & .02 & 1.00 & & \\
OA & .07 & .39 & .45 & 1.00 & 1.00 \\
QL & .12 & .36 & .54 & .60 & \\
\hline
\end{tabular}

\subsection{Post-Hoc Analyses}

\subsubsection{Adjusted Model One}

To sum up the changes based on the initial model: the new model specified for the post-hoc analysis is still a five-factor one but with adjusted items-SK (items 10, 11, 13, and 18), CK (items 2, 6, 14, 19, 23, 25, and 31), IA (items 5, 8, 12, 15, 17, 26, and 32), OA (items 7, 20, 27, and 28) and QL (items 9, 16, 21, and 29); the model was run with the items $13,31,5,28,16$ as the marker variables; paths between SK/OA, SK/QL, and CK/IA were dropped; paths between item 9 and SK, item 20 and CK, items 32 and 17 were added; ML robust was applied.

Results showed that normality of the data was a bit improved but still unsatisfactory, with a Mardia's normalized estimate of $16.12(>5.00)$, though no case needed to be taken out. The average off-diagonal absolute standardized residual was $.05(<2.58)$, and residual distribution was centered around zero and symmetric. The overall model fit was quite improved but still not satisfactory, $\chi^{2}(289)=641.07, \mathrm{GFI}=.90$, and $\mathrm{RMSEA}=.05$, within the $90 \%$ confidence interval between .04 and .06 . Cronbach's $\alpha=0.74$. Altogether 6 iterations were run to reach the convergence.

Parameter estimates showed that all the estimates were statistically significant, yet a slight change in the parameter values was detected. Item 10 (.64) instead of item 13 (.51) loaded highest on SK, which would be used as the marker variable in the third model. The loading of item 32(.28) on IA became lower after covariance (.32) with item 17(.59) was estimated. After the cross-loading path was added, item 20 loaded higher on CK (.37) as compared with on OA (.13), while item 9 loaded higher on SK (.46) compared with on QL (.11). Going back to item 9, the statement "if a person tries too hard to understand a problem, they will most likely end up being confused" relates more to the nature of knowledge regarding its being a complex system rather than bits and pieces of facts. Therefore, this item was kept only to SK in the forthcoming model.

The Wald Test confirmed the above finding that item 20 should not be loaded on OA. Although this statement contains the word "authority" it does not really relate to the source of knowledge as intended, therefore, this path was deleted and the one linked to $\mathrm{CK}$ was kept. 
The ML test showed that there was an error covariance between item 23 and 25. Since both items were under CK and is very likely to generate similar responses, so a path between the two was added. ML test once again showed that item 32 cross-loaded on CK. However, the specific statement (i.e., Some people are born with special gifts and talents) is evidently about IA. Due to its being redundant and complex-an error covariance with item 17 and cross-loading on CK, item 32 was deleted in the third model. Results suggested that item 19 should be loaded on SK, which was considered reasonable and was accepted as a change in the new model. However, item 17 (i.e., Some people just have a knack for learning and others don't), which was suggested to be loading on CK, is basically about one's belief about the ability to learn as predetermined versus as acquired through experience. Thus no change was made to this item. There was an error covariance between item 9 and 10 , thus a path between the two was added.

\subsubsection{Adjusted Model Two}

Respecifications kept the same five-factor model but with adjusted items: SK (items 9, 10, 11, 13, and 18), CK (items 2, 6, 14, 19,20, 23, 25, and 31), IA (items 5, 8, 12, 15, 17, and 26), OA (items 7, 27, and 28) and QL (items 16, 21, and 29); the model was run with the items 10,31, 5, 28, and 16 as the marker variables; no path (except the one between items 32 and 17) was dropped; paths between items 9 and 10, 23 and 25, 19 and SK were added. ML robust was applied.

Results showed that normality of the data was further improved, with a Mardia's normalized estimate of 15.83 $(>5.00)$, but no case needed to be taken out. The average off-diagonal absolute standardized residual was .05 $<<$ 2.58 ), and residual distribution was centered around zero and symmetric. The overall model fit was quite improved and reached a moderate fit, $\chi^{2}(265)=510.81, \mathrm{GFI}=.92$, and RMSEA $=.04$, within the $90 \%$ confidence interval between .04 and .05., Cronbach's $\alpha=.74$. Altogether 6 iterations were run to reach the convergence. The item-factor coefficients, and inter-factor correlations for this model are presented in Table 5 and 6.

All parameters were significant and none of the free parameters was dropped in the Wald Test. It was noted that the loadings of items 19 and 23 on their correspondent factor became lower (below .33) after the covariance paths were added. Although it was again suggested by the ML Test that item 17 should be loaded on CK, due to the reason previously explained, no further change would be made to the present model, which made this our final model (See Appendix C for a final version of EBI-C).

Table 5. Maximum-Likelihood Coefficients for the EBI-C (Final Model)

\begin{tabular}{|c|c|c|c|c|c|c|}
\hline Items & & SK & $\mathrm{CK}$ & IA & $\mathrm{OA}$ & QL \\
\hline 9 & $\begin{array}{l}\text { If a person tries too hard to understand a problem, they } \\
\text { will most likely end up being confused. }\end{array}$ & .31 & & & & \\
\hline 10 & Too many theories just complicate things. & .52 & & & & \\
\hline 11 & The best ideas are often the most simple. & .43 & & & & \\
\hline 13 & Instructors should focus on facts instead of theories. & .52 & & & & \\
\hline 18 & $\begin{array}{l}\text { Things are simpler than most professors would have you } \\
\text { believe. }\end{array}$ & .50 & & & & \\
\hline 2 & Truth means different things to different people. & & .42 & & & \\
\hline 6 & Absolute moral truth does not exist. & & .38 & & & \\
\hline 14 & $\begin{array}{l}\text { I like teachers who present several competing theories } \\
\text { and let their students decide which is best. }\end{array}$ & & .40 & & & \\
\hline 19 & $\begin{array}{l}\text { If two people are arguing about something, at least one } \\
\text { of them must be wrong. }\end{array}$ & .40 & .70 & & & \\
\hline 20 & $\begin{array}{l}\text { Children should be allowed to question their parents' } \\
\text { authority. }\end{array}$ & & .42 & & & \\
\hline 23 & The moral rules I live by apply to everyone. & & .30 & & & \\
\hline 25 & What is true today will be true tomorrow. & & .36 & & & \\
\hline 31 & Sometimes there are no right answers to life's big & & .57 & & & \\
\hline
\end{tabular}


problems.

5 Some people will never be smart no matter how hard they work.

8 Really smart students don't have to work as hard to do well in school.

12 People can't do too much about how smart they are.

15 How well you do in school depends on how smart you are.

17 Some people just have a knack for learning and others don't.

26 Smart people are born that way.

7 Parents should teach their children all there is to know about life.

27 When someone in authority tells me what to do, I usually do it

28 People who question authority are trouble makers.

16 If you don't learn something quickly, you won't ever learn it.

21 If you haven't understood a chapter the first time through, going back over it won't help.

Table 6. Inter-factor correlation matrix for the EBI-C (final model)

\begin{tabular}{llllll}
\hline & SK & CK & IA & OA & QL \\
\hline SK & 1.00 & & & & \\
CK & -.53 & 1.00 & & & \\
IA & .33 & & & 1.00 & \\
OA & & .34 & 0.46 & .58 & \\
QL & & .42 & 0.52 & \\
\hline
\end{tabular}

\section{Discussion and Conclusion}

Our findings showed that the EBI-C measures the same construct of epistemic beliefs in a Chinese population as EBI does in a North American population. The factor structure was more similar than different. The fact that there is no significant correlations between CK and IA, and between SK and QL, supports Hofer and Pintrich's argument (1997) that a distinction should be made between beliefs about knowledge and learning beliefs. From the results it is more defendable that QL and IA are beliefs about learning rather than beliefs about knowledge. The factor of OA was not well predicted by some of the designed items, since two out of five were taken out in the final model. In addition, OA was not significantly correlated with SK. This is likely due to the noted few problematic items, failing to represent the sense of "authority" that the items were meant to measure. Results regarding to the factor of $\mathrm{OA}$ indicate that statements should be designed to reflect the source of knowledge as from being handed down by the authoritative figures (e.g. experts, teachers, parents, text books or formal media) to being reasoned by oneself, rather than referring to obedience to the more powerful. Schommer (1990) failed to report this factor principally because the items she constructed for OA were not able to measure the intended meaning of "authority". Although Schraw, Bendixen and Dunkle $(1998,2002)$ successfully yielded an OA factor, a similar problem still exists with some of the items, even in a Chinese population, which is predicted to have more dispositions to relate to this factor.

\section{Limitations}

The fact that many of the measured variables were complex, cross-loading on two factors indicates that exploratory factor analysis (EFA) would have been preferable before or after the confirmatory factor analysis 
(CFA) was conducted. Other than this a cross-validation would also be a good and direct solution. In addition, since all the observed variables were measured on ordinal scales, treating these variables as if they were continuous by computing correlations is less powerful although it is the usual practice (Byrne, 2006).

The Chinese version of the EBI has been successfully developed. A lot more work needs to be done for more extensive and valid uses of this instrument. However, cross-cultural research becomes more feasible because of the presence of this parallel instrument.

\section{References}

Ayatollahi, M. A., Rasekh, A. E., \& Tavakoli, M. (2012). Learner beliefs, self-regulated learning strategies and 12 academic reading comprehension: A structural equation modeling analysis. World Applied Sciences Journal, 17(1), 36-49.

Bendixen, L. D., Schraw, G., \& Dunkle, M. E. (1998). Epistemic beliefs and moral reasoning. The Journal of Psychology, 13, 187-200. http://dx.doi.org/10.1080/00223989809599158

Bentler, P. M., \& Wu. E. J. C. (2013). EQS 6.1 for Windows user's guide. Retrieved from http://www.mvsoft.com/pub/EQS\%2061\%20QuickStart.pdf

Brislin, R. W., Lonner, W. J., \& Thorndike, R. M. (1973). Cross-cultural research methods. New York, NY: Wiley.

Brownlee, J., Walker, S., Lennox, S., Exley, B., \& Pearce, S. (2009). The first year university experience: using personal epistemology to understand effective learning and teaching in higher education. Higher Education, 58(5), 599-618. http://dx.doi.org/10.1007/s10734-009-9212-2

Buehl, M. M. (2008). Assessing the multidimensionality of students' epistemic beliefs across diverse cultures. In M. S. Khine (Ed.), Knowing, knowledge and beliefs: Epistemological studies across diverse cultures (pp. 65-112). New York, NY: Springer.

Byrne, B. M. (2006). Structural equation modeling with EQS: Basic concepts, applications, and programming (2nd ed.). New York, NY: LEA.

Cam, A., Topcu, M. S., Sulun, Y., Guven, G., \& Arabacioglu, S. (2012). Translation and validation of the Epistemic Belief Inventory with Turkish pre-service teachers. Educational Research and Evaluation, 18(5), 441-458. http://dx.doi.org/10.1080/13803611.2012.689726

Cano, F. (2005). Epistemological beliefs and approaches to learning: Their change through secondary school and their influence on academic performance. British Journal of Educational Psychology, 75(2), 203-221. http://dx.doi.org/10.1348/000709904x22683

Chan, K., \& Elliott, R. G. (2002). Exploratory study of Hong Kong teacher education students' epistemological beliefs: Cultural perspectives and implications on beliefs research. Contemporary Educational Psychology, 27(3), 392-414. http://dx.doi.org/10.1006/ceps.2001.1102

Chan, N. M., Ho, I. T., \& Ku, K. Y. (2011). Epistemic beliefs and critical thinking of Chinese students. Learning and Individual Differences, 21(1), 67-77. http://dx.doi.org/10.1016/j.lindif.2010.11.001

Cole, M., \& Bruner, J. S. (1971). Cultural differences and inferences about psychological processes. American Psychologist, 26, 867-876. http://dx.doi.org/10.1037/h0032240

DeBacker, T. K., Crowson, H. M., Beesley, A. D., Thoma, S. J., \& Hestevold, N. L. (2008). The challenge of measuring epistemic beliefs: An analysis of three self-report instruments. The Journal of Experimental Education, 76(3), 281-312. http://dx.doi.org/10.3200/JEXE.76.3.281-314

Duell, O. K., \& Schommer-Aikins, M. (2001). Measures of people's beliefs about knowledge and learning. Educational Psychology Review, 13(4), 419-449. http://dx.doi.org/10.1023/A:1011969931594

Estes, D., Chandler, M., Horvath, K. J., \& Backus, D. W. (2003). American and British college students' epistemological beliefs about research on psychological and biological development. Journal of Applied Developmental Psychology, 23(6), 625-642. http://dx.doi.org/10.1016/s0193-3973(03)00002-9

Franco, G. M., Muis, K. R., Kendeou, P., Ranellucci, J., Sampasivam, L., \& Wang, X. (2012). Examining the influences of epistemic beliefs and knowledge representations on cognitive processing and conceptual

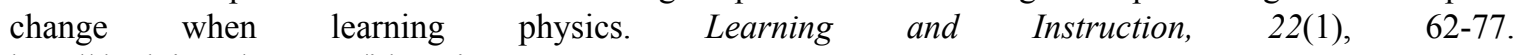
http://dx.doi.org/10.1016/j.learninstruc.2011.06.003 
Gottlieb, E., \& Institute, M. L. (2007). Learning how to believe: Epistemic development in cultural context. Journal of the Learning Sciences, 16(1), 5-35. http://dx.doi.org/10.1080/10508400709336941

Haerle, F. C., \& Bendixen, L. D. (2008). Personal epistemology in elementary classrooms: A conceptual comparison of Germany and the United States and a guide for future cross-cultural research. In M. S. Khine (Ed.), Knowing, knowledge and beliefs: Epistemological studies across diverse cultures (pp. 151-176). New York, NY: Springer.

Hansen, J. I. C. (1987). Cross-cultural research on vocational interests. Measurement and Evaluation in Counseling and Development, 19, 163-176.

Hofer, B. K. (2001). Personal epistemology research: Implications for learning and teaching. Journal of Educational Psychology Review, 13(4), 353-383. http://dx.doi.org/10.1023/A:1011965830686

Hofer, B. K. (2008). Personal epistemology and culture. In M. S. Khine (Ed.), Knowing, knowledge and beliefs: Epistemological studies across diverse cultures (pp. 3-22). New York, NY: Springer.

Hofer, B. K. (April, 2007). Learning strategies and epistemic beliefs: Cultural influences in Japan and the US. Paper presented at the American Educational Research Association, Chicago.

Hofer, B. K., \& Pintrich, P. R. (1997). The development of epistemological theories: Beliefs about knowledge and knowing and their relation to learning. Review of Educational Research, 67(1), 88-140. http://dx.doi.org/10.3102/00346543067001088

Jeong, C. (2003). A cross-cultural study of the relationships between epistemological beliefs and moral judgment as a psychological foundation for moral education (Doctoral dissertation). Retrieved from http://athenaeum.libs.uga.edu/handle/10724/6512

Karabenick, S. A., \& Moosa, S. (2005). Culture and personal epistemology: US and middle eastern students' beliefs about scientific knowledge and knowing. Social Psychology of Education, 8, 375-393. http://dx.doi.org/10.1007/s11218-005-1826-3

Kardash, C. M., \& Howell, K. L. (2000). Effects of epistemological beliefs and topic-specific beliefs on undergraduates cognitive and strategic processing of dual-positional text. Journal of Educational Psychology, 92, 524-535. http://dx.doi.org/10.1037/0022-0663.92.3.524

Kuhn, D., Weinstock, M., \& Flaton, R. (1994). How well do jurors reason? Competence dimensions of individual variation in a juror reasoning task. Psychological Science, 5, 289-296. http://dx.doi.org/10.1111/j.1467-9280.1994.tb00628.x

Laster, B. B. (2010). A structural and correlational analysis of two common measures of personal epistemology (Doctoral dissertation). Retrieved from http://dc.library.okstate.edu/cdm/singleitem/collection/Dissert/id/72628/rec/20

Lonner, W. J. (1985). Issues in testing and assessment in cross-cultural counseling. The Counseling Psychologist, 13, 599-614. http://dx.doi.org/10.1177/0011000085134004

Lonner, W. J. (1990). An overview in cross-cultural testing and assessment. In R. W. Brislin (Ed.), Applied Cross-cultural Psychology. Newbury Park, CA: sage.

Muis, K. R. (2008). Epistemic profiles and self-regulated learning: Examining relations in the context of mathematics problem solving. Contemporary Educational Psychology, 33(2), 177-208. http://dx.doi.org/10.1016/j.cedpsych.2006.10.012

Muis, K. R., \& Franco, G. (2010). Epistemic profiles and metacognition: Support for the consistency hypothesis. Metacognition and Learning, 5, 27-45. http://dx.doi.org/10.1007/s11409-009-9041-9

Muis, K. R., \& Franco, G. M. (2009). Epistemic beliefs: Setting the standards for self-regulated learning. Contemporary Educational Psychology, 34(4), 306-318. http://dx.doi.org/10.1016/j.cedpsych.2009.06.005

Muis, K. R., \& Sinatra, G. M. (2008). University cultures and epistemic beliefs: Examining differences between two academic environments. In M. S. Khine (Ed.), Knowing, knowledge and beliefs: Epistemological studies across diverse cultures (pp. 137-150). New York, NY: Springer.

Nietfeld, J. L., \& Enders, C. K. (2003). An examination of student teacher beliefs: Interrelationships between hope, self-efficacy, goal-orientations, and beliefs about learning. Current Issues in Education, 6(5), 2005. 
Nussbaum, E., \& Bendixen, L. D. (2003). Approaching and avoiding arguments: The role of epistemological beliefs, need for cognition, and extraverted personality traits. Contemporary Educational Psychology, 28(4), 573-595. http://dx.doi.org/10.1016/S0361-476X (02)00062-0

Ordoñez, X. G., Ponsoda, V., Abad, F. J., \& Romero, S. J. (2009). Measurement of epistemological beliefs psychometric properties of the EQEBI test scores. Educational and Psychological Measurement, 69(2), 287-302. http://dx.doi.org/10.1177/0013164408323226

Paechter, M. R., Rebmann, K., Schloemer, T., Mokwinski, B., Hanekamp, Y., \& Arendasy, M. (2013). Development of the Oldenburg Epistemic Beliefs Questionnaire (OLEQ), a German questionnaire based on the Epistemic Belief Inventory (EBI). Current Issues in Education, 16(1), 1-18.

Palmer, B., \& Marra, R. M. (2008). Individual domain-specific epistemologies: Implications for educational practice. In M. S. Khine (Ed.), Knowing, knowledge and beliefs: Epistemological studies across diverse cultures (pp. 325-350). New York, NY: Springer.

Perry, W. G. (1970). Forms of intellectual and ethical development in the college years: A scheme. New York, NY: Holt, Rinehart, and Winston.

Qian, G., \& Pan, J. (2002). A comparison of epistemological beliefs and learning from science text between American and Chinese high school students. In B. K. Hofer, \& P. R. Pintrich (Eds.), Personal epistemology: The psychology of beliefs about knowledge and knowing (pp. 365-386). Mahwah, NJ: Erlbaum.

Ravindran, B., Greene, B. A., \& Debacker, T. K. (2005). Predicting preservice teachers' cognitive engagement with goals and epistemological beliefs. The Journal of Educational Research, 98(4), 222-233. http://dx.doi.org/10.3200/JOER.98.4.222-233

Schommer, M. (1990). Effects of beliefs about the nature of knowledge on comprehension. Journal of Educational Psychology, 82(3), 498-504. http://dx.doi.org/ 10.1037/0022-0663.82.3.498

Schommer, M., Crouse, A., \& Rhodes, N. (1992). Epistemological beliefs and mathematical text comprehension: Believing it is simple does not make it so. Journal of Educational Psychology, 84(4), 435-443. http://dx.doi.org/10.1037/0022-0663.84.4.435

Schraw, G., Bendixen, L. D., \& Dunkle, M. E. (2002). Development and validation of the epistemic beliefs inventory (EBI). In B. K. Hofer, \& P. R. Pintrich (Eds.), Personal epistemology: The psychology of beliefs about knowledge and knowing (pp. 261-275). Mahwah, NJ: Lawrence Erlbaum.

Schreiber, J., \& Al-Ghalib, S. (April, 2007). Beliefs and cognitive processing: An examination of American and Saudi Arabian undergraduates. Paper presented at the American Educational Research Association, Chicago.

So, H. J., Lee, J. Y., Roh, S. Z., \& Lee, S. K. (2010). Examining epistemological beliefs of pre-service teachers in Korea. The Asia-Pacific Education Researcher, 19(1), 79-97.

Sulimma, M. (2009). Relations between epistemological beliefs and culture classifications. Multicultural Education \& Technology Journal, 3(1), 74-89. http://dx.doi.org/10.1108/17504970910951165

Surveygizmo. (2013). Surveygizmo: Powerful and professional survey software. Retrieved from http://www.surveygizmo.com/

Teo, T. (2013). Examining the psychometric properties of the Epistemic Belief Inventory (EBI). Journal of Psychoeducational Assessment, 31(1), 72-79. http://dx.doi.org/10.1177/0734282912449436

Teo, T., \& Chai, C. S. (2011). Confirmatory factor analysis of the Epistemic Belief Inventory (EBI): A cross-cultural study. International Journal of Educational and Psychological Assessment, 9(1),1-13.

Welch, A. G., \& Ray, C. M. (2012). A preliminary report of the psychometric properties of the Epistemic Beliefs Inventory. The European Journal of Social \& Behavioural Sciences, 278-303.

Youn, I. (2000). The cultural specificity of epistemological beliefs about learning. Asian Journal of Social Psychology, 3, 87-105. http://dx.doi.org/10.1111/1467-839X.00056

Zhang, L. F., \& Watkins, D. (2001). Cognitive development and student approaches to learning: An investigation of Perry's theory with Chinese and U.S. university students. Higher Education, 41(3), 239-261. http://dx.doi.org/10.1023/a:1004151226395 
Zhu, C., Valcke, M., \& Schellens, T. (2008). The relationship between epistemological beliefs, learning conceptions, and approaches to study: A cross-cultural structural model? Asia Pacific Journal of Education, 28, 411-423. http://dx.doi.org/10.1080/02188790802468823

\section{Appendix A: Epistemic Beliefs Inventory}

$\mathrm{SK}=$ simple knowledge $(1,10,11,13,18,22,24,30)$

$\mathrm{CK}=$ certain knowledge $(2,6,14,19,23,25,31)$

$\mathrm{IA}=$ innate ability $(5,8,12,15,17,26,32)$

$\mathrm{OA}=$ omniscient authority $(4,7,20,27,28)$

$\mathrm{QL}=$ quick learning $(3,9,16,21,29)$

Reverse code to 5 = naïve beliefs: $2,6,14,20,24,30,31$

1. It bothers me when instructors don't tell students the answers to complicated problems SK

2. Truth means different things to different people CK

3. Students who learn things quickly are the most successful QL

4. People should always obey the law OA

5. Some people will never be smart no matter how hard they work IA

6. Absolute moral truth does not exist $\mathrm{CK}$

7. Parents should teach their children all there is to know about life OA

8. Really smart students don't have to work as hard to do well in school IA

9. If a person tries too hard to understand a problem, they will most likely end up being confused QL

10. Too many theories just complicate things SK

11. The best ideas are often the most simple SK

12. People can't do too much about how smart they are IA

13. Instructors should focus on facts instead of theories SK

14. I like teachers who present several competing theories and let their students decide which is best CK

15. How well you do in school depends on how smart you are IA

16. If you don't learn something quickly, you won't ever learn it QL

17. Some people just have a knack for learning and others don't IA

18. Things are simpler than most professors would have you believe SK

19. If two people are arguing about something, at least one of them must be wrong CK

20. Children should be allowed to question their parents' authority OA

21. If you haven't understood a chapter the first time through, going back over it won't help QL

22. Science is easy to understand because it contains so many facts SK

23. The moral rules I live by apply to everyone CK

24. The more you know about a topic, the more there is to know SK

25 . What is true today will be true tomorrow CK

26. Smart people are born that way IA

27. When someone in authority tells me what to do, I usually do it OA

28. People who question authority are trouble makers OA

29. Working on a problem with no quick solution is a waste of time QL

30. You can study something for years and still not really understand it SK

31. Sometimes there are no right answers to life's big problems CK

32. Some people are born with special gifts and talents IA 


\section{Appendix B: Epistemic Beliefs Inventory- Chinese Version}

认知信念调查问卷

以下每一句陈述都有五个选项，分别是「非常不同意」、「不同意」、「中立」、「同意」、「非常同 意」, 请选择最接近你个人情形的一项。非常感谢!

1.碰到问题如果老师不提供答案的话,我会感到困扰。

2.对真理的认识程度因人而异。

3. 能够快速学习并掌握知识的学生是最成功的。

4. 人们应该始终遵守法律。

5.不管怎么努力有些人就是没法变聪明。

6.绝对的道德准则是不存在的。

7. 父母应该教会孩子所有生活的道理。

8. 真正聪明的学生不需要怎么努力就可以学得很好。

9. 如果人们绞尽脑汁去理解一个问题, 最终他们可能会更困惑。

10.太多理论只会把问题复杂化。

11.最好的想法往往是最简单的。

12. 人有多聪明是自己改变不了的。

13. 老师应侧重于事实知识而不是理论知识。

14. 我喜欢老师同时提供几个对立的理论让学生决定哪个是最好的。

15.学习有多好取决于你有多聪明。

16.如果你不能很快地学会某样东西, 你就永远学不会。

17. 有些人就是对学习有天赋, 而有些人则没有。

18.比起教授们所教的东西, 事情本身通常更简单一些。

19.如果两人就某个事情争论, 至少其中之一必定是错误的。

20.孩子们应该被允许质疑父母的权威。

21. 就某个章节如果第一遍你没读懂, 再读一遍也无济于事。

22 . 科学是很容易理解的, 因为它包含了很多事实知识。

23. 我所遵循的道德准则适用于每个人。

24. 对某个主题了解越深入, 需要知道的也越多。

25. 今天的真理也是明天的真理。

26. 聪明的人生而如此。

27. 当权威人士让我做什么, 我通常照做。

28. 质疑权威就是制造麻烦。

29. 如果一个问题不能快速解决, 试图解决它就是浪费时间。

30.你可以花几年时间学习某样东西却仍然没有真正理解它。

31. 人生有时是没有正确答案的。

32. 有些人生来就有特殊的天赋和才能。

\section{Appendix C: Epistemic Beliefs Inventory- Chinese Version (Final Model)}

认知信念调查问卷

以下每一句陈述都有五个选项，分别是「非常不同意」、「不同意」、「中立」、「同意」、「非常同 意」, 请选择最接近你个人情形的一项。非常感谢!

1. 对真理的认识程度因人而异。 $\mathrm{CK}$

2. 不管怎么努力有些人就是没法变聪明。IA

3. 绝对的道德准则是不存在的。 $\mathrm{CK}$ 
4. 父母应该教会孩子所有生活的道理。OA

5.真正聪明的学生不需要怎么努力就可以学得很好。IA

6. 如果人们绞尽脑汁去理解一个问题, 最终他们可能会更困惑。SK

7.太多理论只会把问题复杂化。SK

8.最好的想法往往是最简单的。SK

9. 人有多聪明是自己改变不了的。IA

10.老师应侧重于事实知识而不是理论知识。SK

11. 我喜欢老师同时提供几个对立的理论让学生决定哪个是最好的。CK

12.学习有多好取决于你有多聪明。IA

13.如果你不能很快地学会某样东西, 你就永远学不会。QL

14. 有些人就是对学习有天赋, 而有些人则没有。IA

15. 比起教授们所教的东西, 事情本身通常更简单一些。SK

16. 如果两人就某个事情争论, 至少其中之一必定是错误的。CK

17.孩子们应该被允许质疑父母的权威。CK

18. 就某个章节如果第一遍你没读懂, 再读一遍也无济于事。QL

19.我所遵循的道德准则适用于每个人。CK

20. 今天的真理也是明天的真理。CK

21.聪明的人生而如此。IA

22.当权威人士让我做什么, 我通常照做。OA

23. 质疑权威就是制造麻烦。OA

24. 如果一个问题不能快速解决, 试图解决它就是浪费时间。QL

25. 人生有时是没有正确答案的。CK

\section{Copyrights}

Copyright for this article is retained by the author(s), with first publication rights granted to the journal.

This is an open-access article distributed under the terms and conditions of the Creative Commons Attribution license (http://creativecommons.org/licenses/by/3.0/). 